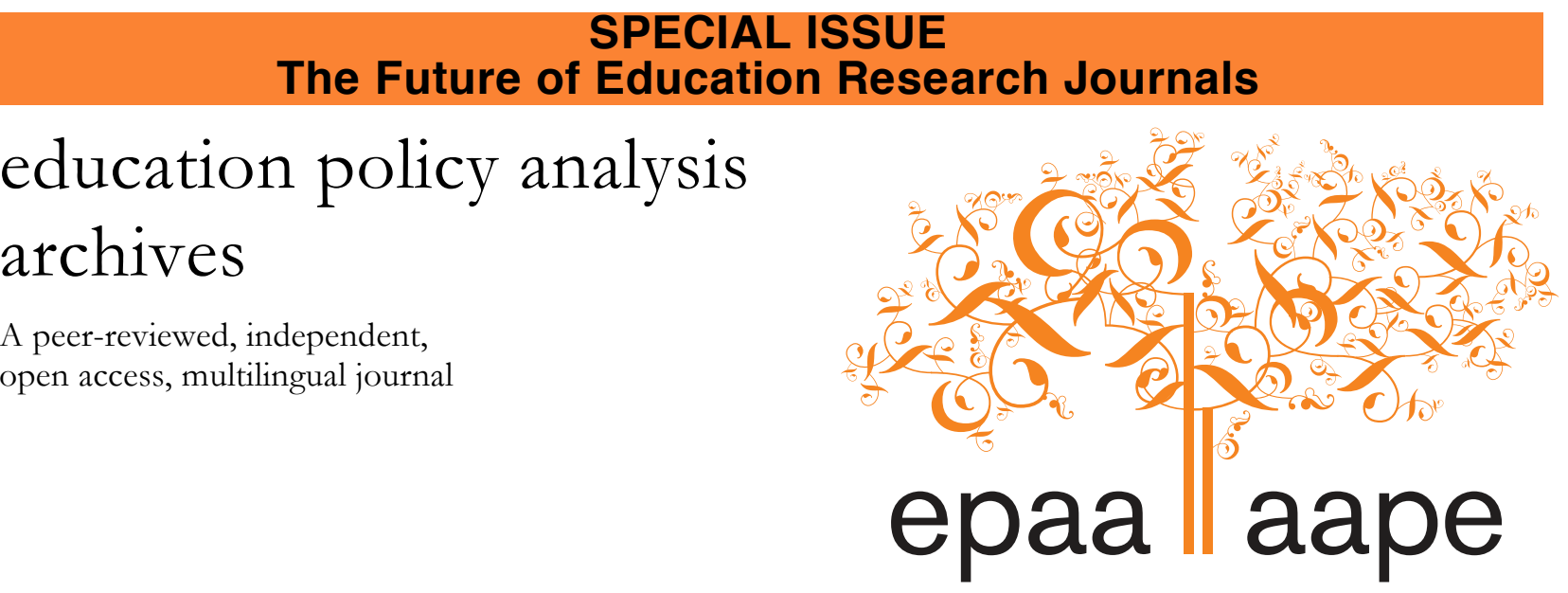

Arizona State University

\title{
The Future of Education Research Publishing: Challenges and Responses
}

\author{
David Post \\ UNESCO GMR \& Pennsylvania State University \\ USA
}

Citation: Post, D. (2014). The future of education research publishing: Challenges and responses. Education Policy Analysis Archives, 22(26). http://dx.doi.org/10.14507/epaa.v22n26.2014 This special issue commentary introduces EPAA/AAPE's Special Issue on The Future of Education Research Journals, Guest Edited by Dr. David Post.

\begin{abstract}
This special issue of Education Policy Analysis Archives addresses scholarly production and publishing (the two are intimately related) in the field of education. Worldwide scholars are facing similar global pressures for "excellence," where the personal and institutional production of relevant scholarship is being compared with simple measures. In some parts of the world, these measures of productivity are fast becoming more immediately consequential than whatever else may be produced as a result of scholarship (purpose, critical reflection, insight, meaning, progress, to list some examples). This essay presents the challenges and responses identified by the eight contributions for this special issue on the future of education research publishing.

Keywords: scholarly communications; academic publishing; education research.

El Futuro de las revistas académicas de investigación en Educación: Desafíos y respuestas Resumen: Este número especial de Archivos Analíticos de Políticas Educativas, aborda la producción académica y editorial (dos procesos que están íntimamente relacionados) en el campo de la investigación en educación. Investigadores/as de todo el mundo se enfrentan a presiones similares para demostrar "excelencia" de sus investigaciones y donde la producción personal e institucional de


conocimientos relevantes está siendo comparada con indicadores simplistas. En algunas partes del mundo, estas medidas de productividad se están convirtiendo rápidamente en los indicadores de mayores consecuencias que cualquier otra conocimiento que se puede producir como resultado de la investigación (ideas, reflexión crítica, visión, sentidos, progresos, para enumerar algunos ejemplos). Este ensayo presenta los desafíos y las respuestas identificadas por las ocho contribuciones para este número especial sobre el futuro de las publicaciones académicas sobre investigación educativa.

Palabras clave: comunicaciones científicas; la publicación académica, la investigación en educación.

\section{O Futuro das revistas acadêmicas de pesquisa em Educação: desafios e respostas}

Resumo: Esta dossiê de Arquivos Analíticos de Politicas Educativas aborda a produção acadêmica e editorial (dois processos intimamente relacionados ) no campo de pesquisa em educação . Pesquisadores/as de todo o mundo enfrentam pressões semelhantes para demonstrar a "excelência" das suas pesquisas e onde a produção pessoal e institucional de conhecimento relevante está sendo avaliada com indicadores simplórios. Em algumas partes do mundo, essas medidas de produtividade estão rapidamente se tornando nos indicadores de maior consequências do que qualquer outro conhecimento que pode ocorrer como resultado de uma pesquisa (ideias, pensamento crítico, planejamentos, sentidos, avanços, para listar só alguns exemplos) . Este artigo apresenta os desafios e as respostas identificadas pelas oito contribuições para esta dossiê sobre o futuro das revistas acadêmicas de pesquisa em Educação.

Palavras-chave: comunicações científicas; publicações acadêmicas; pesquisa em educação.

\section{Introduction}

How will future education inquiry be read, published, or valued? And, on what basis will it ultimately be thought to matter? This special issue of Education Policy Analysis Archives addresses scholarly production and publishing (the two are intimately related) in one field of scholarship, that of education research. But, worldwide, there are many other research fields with strong national traditions - jurisprudence, social work, philosophy, poetry among others - where scholars now face similar global pressures for "excellence" (competitively defined) and where the personal and institutional production of excellent scholarship is being compared with simple measures. In some parts of the world, these measures of productivity are fast becoming more consequential than whatever else may be produced as a result of scholarship (purpose, critical reflection, insight, meaning, progress, to list some examples). This is so because simple measures of productivity currently are being used by central funding agencies to justify the distribution of financial resources to the researchers' institutions and the support of individual scholars as workers.

Let me offer a few more words of retrospect in order to underscore the importance of the eight contributions for this special issue of EPAA. All who have observed changes in higher education agree there has been a convergence in the structures and expectations of postsecondary institutions, despite the fact that education systems grew from diverse historical roots. But there are at least two competing interpretations of the apparent isomorphism of universities, degrees, and research production. One interpretation derives from the Weberian idea of bureaucratic authority, and sees the regulation of knowledge as a natural and neutral outgrowth of rationalized systems of production. In this view, the language that spread from the southern half of one North Atlantic island (i.e. England), following the Bible translations and the Shakespearean verse in the 17th Century, is today a convenient, neutral, and universal medium for commerce and exchange, while it remains as the vernacular language among populations of a few powerful counties. This approach deemphasizes the actors, interest groups, and powers responsible for convergence. A competing 
perspective sees coercion and contestation by political actors, and deemphasizes the global character of change by emphasizing the dynamic over language in particular contested terrains of nations.

The outcomes of these contests, adoptions, and regulations of language matter hugely because of the close relation between language and thought. While one could cite European postmodernists to make this point, I want to mention a Connecticut Yankee fire insurance inspector working during the 1930s, an American writing in my own vernacular language, Benjamin Lee Whorf, who created the field of psycholinguistics. In summarizing his linguistics research on the cultures native to Central America, the Southwestern United States, and Alaska, Whorf wrote:

We dissect nature along lines laid down by our native languages.... We cut nature up, organize it into concepts, and ascribe significances as we do, largely because we are parties to an agreement to organize it in this way-an agreement that holds throughout our speech community and is codified in the patterns of our language. The agreement is, of course, an implicit and unstated one, but its terms are absolutely obligatory; we cannot talk at all except by subscribing to the organization and classification of data which the agreement decrees. (In Carroll, 1956, p. 212-213) Whorf was talking about individual communication, but, at a different level, the agreements (voluntary or otherwise) that are accepted about the organization and classification of ideas on what is important are what make intercultural communication possible. Defining these agreements and making them explicit can help both potential users and producers of research recognize the limitations as well as the opportunities for the scholarship generated and published in the field. And, in post-secondary education, the repercussions of Whorf's simple point are being felt in unanticipated ways.

The chief implication comes from the global drive for "world class" universities, which is associated with a movement to create research quality assessment indictors. These related developments foretell different futures for higher education. On the one hand, and very positively, globalization increases the contact and sharing of information, values, and questions (exactly as we are doing here in this special issue). Globalization also promotes competition, and this may increase productivity on shared research agendas. Less positively, this drive increases the risk of homogenization by promoting a single common language of scholarship (usually English), and by prioritizing certain research journals in research assessment exercises (nearly all "ranked" journals are published in North America and Europe). In many countries with centralized research funding, journals are classified as either "domestic" or "international." By awarding local journals lower assessment scores, this classification may have the unintended consequence of discouraging research that is inherently difficult to communicate to English-language readers - for example, research about Cantonese versus Mandarin Chinese media of instruction in the case of Hong Kong, Japanese anthropology, or Sinhalese literature. Are non-English literatures and topics of less interest to nonEnglish speakers, being supported in a publishing regime that prioritizes publication in English?

The first three contributions to this special issue could be read as a conversation about what should be done by three different types of agents: editors, individual scholars, and scholars as organized collectives. Kathryn Anderson-Levitt writes from her perspective as the former editor of Anthropology of Education Quarterly, and from her current coeditorship of Comparative Education Review. Her essay problematizes the myopia of many U.S.-based journals, which are unable to discern the questions important to users of vernacular languages other than English. This is a loss for English monolinguals. Anderson-Levitt offers advice for bringing non-English scholarship to US readers, while simultaneously helping scholars in other countries by coaching them in the expectations of international journals - a practice that a few very good English-language journals have publically committed to do. 
Next in the special issue, Suresh Canagarajah documents the lived experiences of young scholars in a Southeast Asian university where he was invited as a distinguished visitor and a "literacy broker" (to use the terminology by two other authors we include, Mary Ann Curry and Theresa Lillis). Canagarajah tried to do exactly what Anderson-Levitt advised, educating his mentees to the norms of publication in the dominant journals. At the same time, he collected critical insights about how the expectations of publication in those journals were affecting the agendas of his mentees. To Canagarajah's surprise, this critique was subsequently deemed so sensitive that some participants decided they did not wish even to be indirectly referenced (hence the anonymity of the university and even the name of the country in the article). As he explains, "the scholars felt that even pseudonyms and anonymity will not provide them sufficient protection, as the details in their drafts and journals can reveal the context and identity." A conversation between Anderson-Levitt and Canagarajah might focus on the power asymmetry between journal editors and the prospective authors to their journals (who are also potential authors for merely "local" journals).

But not all responses to power imbalance are individual responses alone; some are collective. This is the example of Taiwan, where Chuing Prudence Chou has analyzed the consequence of a central higher education policy that incentivized social scientists to publish in a list of journals recognized by the Social Science Citation Index (SSCI), nearly all English media. In response to these incentives, in 2010 over 3,000 Taiwanese university faculty (mostly from the social sciences, not natural sciences) signed a petition demanding that the government discontinue the use of SSCI journals as the indicator for university productivity. In addition this petition urged funding agencies to expand both the quantity and the variety of acceptable academic journals including many local journals published in Chinese. Finally, as signatures increased, top government officials agreed in 2012 to make changes in the listing of acceptable journals. A conversation between Professors Chou, Canagarajah, and Anderson-Levitt might turn to the reasons that collective responses are more or less likely, and more or less likely to have an effect, in some countries rather than others.

Writing from Japan, Mayumi Ishikawa documents the sensitivity not only of scholars but of entire countries to global pressures. In 2010, as she relates, there were new rankings of universities produced by a commercial firm, Times Higher Education (THE) in collaboration with ThomsonReuters. Only five Japanese universities were listed among the world's top 200, compared with eleven in the previous year. Also, as Ishikawa explains, Asia's top position went to the University of Hong Kong, replacing the University of Tokyo. While Japan's response is still evolving, there is a "bipolarity," a tension between the orientations of the broadly identified STEM sciences and the social sciences and humanities. Both responses may be necessary. As she writes, "there is no doubt that raising English-language paper productivity in the humanities and social sciences matters for Japan's future. It is a critical step on the path to promoting globally engaged research, while ensuring connectivity and fostering dialogue with international scholarly communities. Doing so while upholding the scholarly commitment to local society means that researchers play dual roles, a demanding task, to say the least."

Also in this special issue, writing from his position as both a South African university leader and as a scholar of comparative education, Crain Soudien identifies the national responsibility to attend to recognize "the need for academics to attend to problematiques available in their own local spaces." This may sound easy, but Soudien's documentation of journal publication patterns shows that it is not. As he writes, "there is real difficulty facing those who develop and implement policy in crafting reward and incentive systems that nurture the conditions for the achievement of both rigor and relevance." Surely one complexity is that the authors themselves are far from passive victims of global pressure. This is one point explicitly made by Mary Jane Curry and Theresa Lillis, based on their past work and on experiences of multilingual scholars in their use of language related 
tactics in "pursuit of their own interests and objectives, particularly in cases where these do not align with official objectives and strategies." These coauthors show that these tactics include publishing in multiple languages and genres as well as developing English-medium national journals. A conversation between Professors Ishikawa, Soudien, and Curry \& Lillis might start with the question about what makes the optimal response from Japan different from those in England and South Africa.

Two final pieces included in this collection offer more abstract insights based on two different strategies. Writing from the U.S., Leslie D. Gonzales and Anne-Marie Núñez share an exhaustive literature review about what they call the "ranking regime." Their work enriches our understanding of the ways that ranking has been understood in the literature to influence scholarly work by influencing its evaluation. Gonzales and Núñez synthesize much emerging writing on the area to show that there are four key processes believed to shape the production of scholarship under these ranking regimes: individualism, standardization, commodification, homogenization. Editors themselves are not bystanders in these processes (as Anderson-Levitt acknowledges, and as I myself fervently agree). Based on his experience in Spanish-language countries of the Americas (and now writing from the USA), Jorge Delgado has done a true service to our thinking by offering the first full model I have seen about the ways that higher education institutions support (or do not) journal production. Delgado's diagram is a step forward in testing out the varied ways that higher education institutions themselves can differ cross-nationally in their responsiveness to the new homogenizing pressures for publication as a commodity (Delgado has done another service by parallel publishing a Spanish version of his essay)

These essays raise persistent questions, some of them normative and some empirical. Independent of this special issue, four contributors (in addition to myself) are collaborating in a project supported by the World University Network to document the changes inside higher education as a consequence of quality assessment based on ranked journals and rank scholarship. We hope to report to you in the near future how publication patterns and topics have changed over the past 20 years, and we plan to record the retrospective appraisals by scholars across different countries. My introduction concludes with a note of gratitude to the dozens of external reviewers who made possible the improvement of the pieces selected for this issue. I also thank my many colleagues in the U.S. and in UNESCO for their patience and support. Most of all, the inspiration for this issue - though jointly shared - was enabled only through the instigation by, and a collegial kick in the pants from, Mr. Gustavo Fischman, whose stewardship of the EEPA has been inspirational to so many authors and editors worldwide.

\section{References}

Carroll, J.B. (1956). Language, Thought, and Reality: Selected Writings. Cambridge, MA: Massachusetts Institute of Technology Press. 


\section{About the Guest Editor}

David Post

UNESCO GMR \& Pennsylvania State University

profdavidpost@gmail.com

David Post is Senior Policy Analyst with the Global Monitoring Report of Education For All, and is currently based at UNESCO in Paris. He also is a Professor of Comparative and International Education who is on leave from Penn State University in the USA. He has researched and published about educational stratification, about child labor issues, as well as the politics of educational mobilization. He also investigates the impact of concurrent employment on student academic achievement. He has been a visiting professor at the Colegio de México, at the Facultad Latinoamericana de Ciencias Sociales, and at the Hong Kong University of Science and Technology. Finally, David served for ten years as editor of Comparative Education Review, where he became concerned about the commodification of scholarship and the possible responses to it by intellectuals, for example through peer-reviewed, open access publication of studies like those in this special issue. Last year, the EPAA printed the Spanish version of his commentary, "Los Rankings Académicos." http://epaa.asu.edu/ojs/article/view/1347

\section{SPECIAL ISSUE
The Future of Education Research Journals education policy analysis archives}

Volume 22 Number 26 May 5 $5^{\text {th }}, 2014 \quad$ ISSN 1068-2341

SOMAERIGHISRESERVED Readers are free to copy, display, and distribute this article, as long as the work is attributed to the author(s) and Education Policy Analysis Archives, it is distributed for noncommercial purposes only, and no alteration or transformation is made in the work. More details of this Creative Commons license are available at http://creativecommons.org/licenses/by-nc-sa/3.0/. All other uses must be approved by the author(s) or EPAA. EPAA is published by the Mary Lou Fulton Institute and Graduate School of Education at Arizona State University Articles are indexed in CIRC (Clasificación Integrada de Revistas Científicas, Spain), DIALNET (Spain), Directory of Open Access Journals, EBSCO Education Research Complete, ERIC, Education Full Text (H.W. Wilson), QUALIS A2 (Brazil), SCImago Journal Rank; SCOPUS, SOCOLAR (China).

Please contribute commentaries at http://epaa.info/wordpress/ and send errata notes to Gustavo E. Fischman fischman@asu.edu

Join EPAA's Facebook community at https://www.facebook.com/EPAAAAPE and Twitter feed@epaa_aape. 


\section{education policy analysis archives editorial board}

Editor Gustavo E. Fischman (Arizona State University)

Associate Editors: Audrey Amrein-Beardsley (Arizona State University), Rick Mintrop, (University of California, Berkeley) Jeanne M. Powers (Arizona State University)

Jessica Allen University of Colorado, Boulder

Gary Anderson New York University

Michael W. Apple University of Wisconsin, Madison

Angela Arzubiaga Arizona State University

David C. Berliner Arizona State University

Robert Bickel Marshall University

Henry Braun Boston College

Eric Camburn University of Wisconsin, Madison

Wendy C. Chi* University of Colorado, Boulder

Casey Cobb University of Connecticut

Arnold Danzig Arizona State University

Antonia Darder University of Illinois, UrbanaChampaign

Linda Darling-Hammond Stanford University

Chad d'Entremont Strategies for Children

John Diamond Harvard University

Tara Donahue Learning Point Associates

Sherman Dorn University of South Florida

Christopher Joseph Frey Bowling Green State University

Melissa Lynn Freeman* Adams State College

Amy Garrett Dikkers University of Minnesota

Gene V Glass Arizona State University

Ronald Glass University of California, Santa Cruz

Harvey Goldstein Bristol University

Jacob P. K. Gross Indiana University

Eric M. Haas WestEd

Kimberly Joy Howard* University of Southern California

Aimee Howley Ohio University

Craig Howley Ohio University

Steve Klees University of Maryland

Jaekyung Lee SUNY Buffalo
Christopher Lubienski University of Illinois, UrbanaChampaign

Sarah Lubienski University of Illinois, UrbanaChampaign

Samuel R. Lucas University of California, Berkeley

Maria Martinez-Coslo University of Texas, Arlington William Mathis University of Colorado, Boulder Tristan McCowan Institute of Education, London Heinrich Mintrop University of California, Berkeley Michele S. Moses University of Colorado, Boulder Julianne Moss University of Melbourne Sharon Nichols University of Texas, San Antonio Noga O'Connor University of Iowa

João Paraskveva University of Massachusetts, Dartmouth

Laurence Parker University of Illinois, UrbanaChampaign

Susan L. Robertson Bristol University

John Rogers University of California, Los Angeles

A. G. Rud Purdue University

Felicia C. Sanders The Pennsylvania State University Janelle Scott University of California, Berkeley

Kimberly Scott Arizona State University

Dorothy Shipps Baruch College/CUNY

Maria Teresa Tatto Michigan State University

Larisa Warhol University of Connecticut

Cally Waite Social Science Research Council

John Weathers University of Colorado, Colorado Springs

Kevin Welner University of Colorado, Boulder

Ed Wiley University of Colorado, Boulder

Terrence G. Wiley Arizona State University

John Willinsky Stanford University

Kyo Yamashiro University of California, Los Angeles

* Members of the New Scholars Board 


\section{archivos analíticos de políticas educativas consejo editorial}

Editor: Gustavo E. Fischman (Arizona State University)

Editores. Asociados Alejandro Canales (UNAM) y Jesús Romero Morante (Universidad de Cantabria)

Armando Alcántara Santuario Instituto de Investigaciones sobre la Universidad y la Educación, UNAM México

Claudio Almonacid Universidad Metropolitana de Ciencias de la Educación, Chile

Pilar Arnaiz Sánchez Universidad de Murcia, España

Xavier Besalú Costa Universitat de Girona, España Jose Joaquin Brunner Universidad Diego Portales, Chile

Damián Canales Sánchez Instituto Nacional para la Evaluación de la Educación, México

María Caridad García Universidad Católica del Norte, Chile

Raimundo Cuesta Fernández IES Fray Luis de León, España

Marco Antonio Delgado Fuentes Universidad Iberoamericana, México

Inés Dussel FLACSO, Argentina

Rafael Feito Alonso Universidad Complutense de Madrid, España

Pedro Flores Crespo Universidad Iberoamericana, México

Verónica García Martínez Universidad Juárez Autónoma de Tabasco, México

Francisco F. García Pérez Universidad de Sevilla, España

Edna Luna Serrano Universidad Autónoma de Baja California, México

Alma Maldonado Departamento de Investigaciones Educativas, Centro de Investigación y de Estudios Avanzados, México

Alejandro Márquez Jiménez Instituto de Investigaciones sobre la Universidad y la Educación, UNAM México

José Felipe Martínez Fernández University of California Los Angeles, USA
Fanni Muñoz Pontificia Universidad Católica de Perú

Imanol Ordorika Instituto de Investigaciones Economicas - UNAM, México

Maria Cristina Parra Sandoval Universidad de Zulia, Venezuela

Miguel A. Pereyra Universidad de Granada, España

Monica Pini Universidad Nacional de San Martín, Argentina

Paula Razquin UNESCO, Francia

Ignacio Rivas Flores Universidad de Málaga, España

Daniel Schugurensky Universidad de Toronto-Ontario Institute of Studies in Education, Canadá

Orlando Pulido Chaves Universidad Pedagógica Nacional, Colombia

José Gregorio Rodríguez Universidad Nacional de Colombia

Miriam Rodríguez Vargas Universidad Autónoma de Tamaulipas, México

Mario Rueda Beltrán Instituto de Investigaciones sobre la Universidad y la Educación, UNAM México

José Luis San Fabián Maroto Universidad de Oviedo, España

Yengny Marisol Silva Laya Universidad Iberoamericana, México

Aida Terrón Bañuelos Universidad de Oviedo, España

Jurjo Torres Santomé Universidad de la Coruña, España

Antoni Verger Planells University of Amsterdam, Holanda

Mario Yapu Universidad Para la Investigación Estratégica, Bolivia 


\section{arquivos analíticos de políticas educativas conselho editorial}

Editor: Gustavo E. Fischman (Arizona State University) Editores Associados: Rosa Maria Bueno Fisher e Luis A. Gandin

(Universidade Federal do Rio Grande do Sul)

Dalila Andrade de Oliveira Universidade Federal de Minas Gerais, Brasil

Paulo Carrano Universidade Federal Fluminense, Brasil

Alicia Maria Catalano de Bonamino Pontificia Universidade Católica-Rio, Brasil

Fabiana de Amorim Marcello Universidade Luterana do Brasil, Canoas, Brasil

Alexandre Fernandez Vaz Universidade Federal de Santa Catarina, Brasil

Gaudêncio Frigotto Universidade do Estado do Rio de Janeiro, Brasil

Alfredo M Gomes Universidade Federal de Pernambuco, Brasil

Petronilha Beatriz Gonçalves e Silva Universidade Federal de São Carlos, Brasil

Nadja Herman Pontificia Universidade Católica -Rio Grande do Sul, Brasil

José Machado Pais Instituto de Ciências Sociais da Universidade de Lisboa, Portugal

Wenceslao Machado de Oliveira Jr. Universidade Estadual de Campinas, Brasil
Jefferson Mainardes Universidade Estadual de Ponta Grossa, Brasil

Luciano Mendes de Faria Filho Universidade Federal de Minas Gerais, Brasil

Lia Raquel Moreira Oliveira Universidade do Minho, Portugal

Belmira Oliveira Bueno Universidade de São Paulo, Brasil

António Teodoro Universidade Lusófona, Portugal

Pia L. Wong California State University Sacramento, U.S.A

Sandra Regina Sales Universidade Federal Rural do Rio de Janeiro, Brasil

Elba Siqueira Sá Barreto Fundação Carlos Chagas, Brasil

Manuela Terrasêca Universidade do Porto, Portugal

Robert Verhine Universidade Federal da Bahia, Brasil

Antônio A. S. Zuin Universidade Federal de São Carlos, Brasil 